\title{
Effects of propeller scarring on macrofaunal use of the seagrass Thalassia testudinum
}

\author{
Amy V. Uhrin ${ }^{1,2, *}$, Jeff G. Holmquist ${ }^{1,3,4}$ \\ ${ }^{1}$ Department of Marine Science, University of Puerto Rico, Mayagüez Campus, PO Box 908, Lajas, Puerto Rico 00667, USA \\ ${ }^{2}$ NOAA, National Ocean Service, Center for Coastal Fisheries and Habitat Research, 101 Pivers Island Road, Beaufort, \\ North Carolina 28516, USA \\ ${ }^{3}$ White Mountain Research Station, University of California, 3000 East Line Street, Bishop, California 93514, USA \\ ${ }^{4}$ Marine Science Institute, University of California Santa Barbara, Star Route 1, PO Box 198, Mammoth Lakes, \\ California 93546, USA
}

\begin{abstract}
Propeller scarring within seagrass beds is common in shallow coastal waters. Scarring has the potential to fragment seagrass beds, resulting in habitat loss, decreased productivity, and the possibility for further erosion and degradation. We conducted a study in Thalassia testudinum beds in Puerto Rico to determine whether seagrass macrofauna are affected by this disturbance. Four sampling zones (propeller scar, seagrass-scar interface, homogeneous seagrass located $5 \mathrm{~m}$ from the scar, and homogeneous seagrass located $10 \mathrm{~m}$ from the scar) were compared among 10 replicate seagrass beds. Scarring modified faunal assemblages at the scale of the propeller scar; there was significantly lower total macrofaunal abundance and fewer species in scars. When individual taxa were considered, shrimp and mollusc abundances were lower in scars compared to the other sampling zones. Resident fish abundance was not significantly different among zones. Dominant shrimp species in scars differed from seagrass zones. Crabs and molluscs responded negatively to scarring as indicated by significantly lower densities of these 2 taxa up to $5 \mathrm{~m}$ from scars. The extent to which these results 'scale up' remains unknown and future studies should focus on larger, more intensely scarred areas.
\end{abstract}

KEY WORDS: Propeller scarring · Edge · Seagrass · Thalassia testudinum · Decapoda · Shrimp · Fish · Molluscs Resale or republication not permitted without written consent of the publisher

\section{INTRODUCTION}

Fragmentation of native habitat is believed to be one of the major reasons for decreases in world biodiversity (Wilcox \& Murphy 1985, Majer et al. 1997). In addition to the direct removal of structure, fragmentation modifies physical processes and landscape configuration. One such modification is the increase of edge habitat relative to interior habitat. The subsequent expansion of edge effects is thought to be the leading factor promoting ecological changes resulting from habitat fragmentation (Lovejoy et al. 1986). As the edge to perimeter ratio increases during fragmentation (Forman 1995), edge characteristics penetrate further into the interior habitat, creating the potential for changes in faunal spatial distributions and abundance patterns

*Email: amy.uhrin@noaa.gov
(Ozanne et al. 1997, Bender et al. 1998, Stevens \& Husband 1998).

The effects of habitat fragmentation, especially the formation of edges and remnant patches, are of critical concern for conservation biologists (Wilcox \& Murphy 1985, Saunders et al. 1991, Gascon et al. 2000). The degree to which habitat fragmentation disrupts animal dispersal depends upon organism mobility and the scale of fragmentation under investigation (Doak et al. 1992). Although terrestrial fragmentation has been widely examined, fragmentation in marine systems has received little attention (McNeill \& Fairweather 1993, Strong \& Bancroft 1994, Hastings et al. 1995, Frost et al. 1999, Barberá-Cebrián et al. 2002). Because seagrass beds are dominant features in the coastal zone, where human populations continue to rise, there is 
tremendous potential for fragmentation resulting from disturbances linked to human activities such as wading (Eckrich \& Holmquist 2000), dock and boardwalk construction (Burdick \& Short 1999), boat anchoring (Walker et al. 1989, Creed \& Amado Filho 1999), and boat operation in shallow water that often leads to scarring of seagrass beds by propellers (Zieman 1976, Sargent et al. 1995, Bell et al. 2002). Scarring, a unique process in which narrow trenches are created within a seagrass bed, may be severe in some regions (Gonzalez-Liboy 1979, Eleuterius 1987, Fonseca 1994, Sargent et al. 1995, Bell et al. 2002). Seagrass recolonization within scars may be slow, ranging from 2 to $10 \mathrm{yr}$ for Thalassia testudinum (Zieman 1976, Durako et al. 1992, Dawes et al. 1997).

Because scarring events remove seagrass, and because seagrasses reduce current velocities (Fonseca et al. 1982), stabilize sediments (Orth 1977), and recycle nutrients (Fonseca 1996), scars may cause environmental modification on a local scale. For example, scarring may lead to an increase in the amount of edge-like habitat found within the seagrass bed due to the introduction of bare substrate into a meadow. Seagrass fauna would be expected to respond to this habitat modification via behavioral changes because of habitat preference.

The direct loss of habitat that normally occurs during a scarring event has led to the assumption that this type of disturbance has a detrimental effect on seagrass faunal communities. Faunal responses to natural seagrass edges are a current theme in the seagrass literature (Bologna \& Heck 1999, 2002, Frost et al. 1999, Bell et al. 2001), but there is little information on the responses of fauna to scarring, although Bell et al. (2002) found few large-scale differences in fauna between scarred and unscarred areas. The paucity of data concerning this phenomenon leads to the question of whether individual scars and their associated edges are large enough to shift faunal distributions.

This study evaluates the potential impacts of individual propeller scars on Puerto Rican seagrass communities, focusing on responses of 4 macrofaunal groups: shrimp, crabs, molluscs, and fish, as these taxa have a well-documented association with seagrass and serve as prey items for local economically important species. Specifically, we tested the null hypothesis that no difference in the abundance and composition of seagrassassociated macrofauna among scar, edge, and interior regions of seagrass beds occurred.

\section{MATERIALS AND METHODS}

Study area and sampling design. This study was conducted between May and November 1999 off the south- west coast of Puerto Rico near La Parguera $\left(17^{\circ} 58^{\prime} \mathrm{N}\right.$, $67^{\circ} 03^{\prime} \mathrm{W}$; Fig. 1). The area consists of a number of inshore and offshore coral reefs, scattered mangrove islands, and seagrass beds within the inner insular shelf. The dominant seagrass species is Thalassia testudinum, but beds may be interspersed with Halodule wrightii and/or Syringodium filiforme. Historical and recent data collected from US Tidal Reference Station 975-9110 at Isla Magueyes indicated that the daily tidal flux in this region was minimal, with a mean daily flux of $0.15 \mathrm{~m}$ for days when sampling occurred.

By sampling existing propeller scars, we were able to assess conditions over a wide (albeit unknown) range of scar ages. Scars were readily recognized as recent injuries ( $<6$ mo old), with no signs of additional erosion beyond that of the original scar path. Ten monospecific Thalassia testudinum beds were chosen based upon level of scarring and amount of contiguous seagrass within the bed. Water depth ranged from 0.5 to $1.6 \mathrm{~m}$. Each site contained a single propeller scar that was bordered by at least $20 \mathrm{~m}$ of continuous seagrass on one side (to allow for designation of sampling zones and to prevent influence from the natural edge of the bed) and $10 \mathrm{~m}$ on the other (again, to buffer against natural edge influence). Scars ranged from 4 to $129 \mathrm{~m}$ in length, 0.25 to $0.76 \mathrm{~m}$ in width, and 0.03 to $0.12 \mathrm{~m}$ in depth. We sought to include a range of scar morphologies in order to make our results more generally applicable. Scars $\geq 30 \mathrm{~m}$ in length were subdivided into $10 \mathrm{~m}$ divisions with one of the divisions chosen randomly as the sampling area. Four sampling zones were distinguished per site: propeller scar (bare sand trench resulting from prop dredging), edge (seagrass within $0.25 \mathrm{~m}$ of the scar), $5 \mathrm{~m}$ interior (distance of $5 \mathrm{~m}$ from the scar), and $10 \mathrm{~m}$ interior (distance of $10 \mathrm{~m}$ from the scar). Seagrass zones were designated on the side of the scar containing the greatest amount of contiguous seagrass. The scars were measured for length and divided into 10 equal-length sections, each marked with a piece of surveyor's tape attached to a galvanized nail to enhance the visibility of each section from above the water's surface. Sections were marked in the same manner in the edge zone. Two parallel lines, the same length as the scar, were established 5 and $10 \mathrm{~m}$ from the scar. The lines were divided into the same equal-length sections as the scar and edge zones. Three different sections from within each zone (scar, edge, $5 \mathrm{~m}, 10 \mathrm{~m}$ ) were randomly chosen for faunal sampling. Because scar lengths varied, sampling locations varied in proximity. Each site was completely sampled over a maximum of $5 \mathrm{~d}$. To ensure that the scar-seagrass transition was well sampled, scar and edge samples were taken as close as possible to scar margins.

Fauna. Seagrass fauna were sampled using a drop trap modified from that of Holmquist (1997). The di- 
mensions of the trap were reduced to $0.25 \times 0.25 \mathrm{~m}$ to allow the trap to fit into each scar without including any seagrass. These types of traps have proven to be highly efficient for sampling small organisms (decapods and small fish) and are the recommended method for faunal surveys in subtidal unvegetated habitats as well as seagrass (Rozas \& Minello 1997). Although drop traps efficiently sample demersal seagrass canopy fauna, sediment surface dwellers and highly mobile fishes are generally under-sampled (Sogard et al. 1987). Target organisms for this study included decapods, small fish, and molluscs, as these taxa commonly occur in seagrass beds and are efficiently captured via drop trap. No attempt was made to quantify larger species as the required sampling gear can be disruptive, ineffective in vegetation (Rozas \& Minello 1997), and too large to exclude seagrass from scar samples. Three random sections from within each zone were selected for sampling with the restriction that there was a minimum 2-section distance between samples taken from adjacent zones. Sampling times of 08:00, 12:00, and 16:00 h were randomly assigned to each of 3 sampling days to encompass daily fluctuation, if any, in animal abundance; thus avoiding temporal pseudoreplication (Hurlbert 1984). There was a minimum of $24 \mathrm{~h}$ between samplings. On each day, 1 section from within each zone was trapped.

It was necessary to lower rather than throw the trap because of the precision of placement required. In order to minimize disturbance, the trap was lowered with a $1.5 \mathrm{~m}$ PVC handle. The handle gripped the trap with a Vise-Grip ${ }^{\circledR}$ locking panel clamp. Using the handle, the trap was carried to the appropriate zone section by field personnel, placed on the substrate, and pushed 1 to $2 \mathrm{~cm}$ into the sediment. A weighted screen was placed over the trap aperture, which was easily lifted and lowered during the clearing process. The trap was held in place with lead weights suspended from each corner. Fauna were cleared from the trap by passing a $0.25 \mathrm{~m}$ wide, handled net ( $2 \mathrm{~mm}$ mesh) through the trap at the water-sediment interface. The net was emptied of its contents into a $19 \mathrm{l}$ plastic bucket filled with seawater. Ten net passes were made in each trap, removing $\sim 95 \%$ of target fauna (A. Uhrin pers. obs., Holmquist 1997, Eckrich \& Holmquist 2000, Bell et al. 2002). Buckets were transported to the laboratory where shrimp, fish, crabs, and molluscs were sorted live, enumerated, and identified to species, with the exception of crabs, which were grouped as either Brachyura or Anomura. Total faunal abundance (abundance of individuals from all groups combined) and abundances within each group were determined and scaled to per $\mathrm{m}^{2}$ values. Number of species per $0.25 \mathrm{~m}^{2}$ was also calculated. Shrimp species comprising less than $9 \%$ of the total number of individuals collected were pooled for some analyses. Molluscs and fish were treated similarly.

Data analysis. Comparisons for total macrofaunal abundance, number of species, and abundance of individual species were made among the following zones: scar and edge, scar and $5 \mathrm{~m}$, scar and $10 \mathrm{~m}$, edge and 5 $\mathrm{m}$, edge and $10 \mathrm{~m}, 5$ and $10 \mathrm{~m}$. Normality was tested using the Shapiro-Wilk test (SAS Institute 1999). Bartlett's test and the F-max test (SAS Institute 1999) were used to test for homogeneity of variances. In order to meet the above assumptions various transformations were necessary. Total fauna abundance and total number of shrimp were $\sqrt{(y+0.5)}$ transformed. Abundances of Thor manningi, Hippolyte zostericola/pleuracanthus, Periclimenes americanus, Latreutes fucorum, Cerithium eberneum, Cerithiopsis greenii, Tricolia bella, and Modulus modulus were log $(y+1)$ transformed, as were pooled shrimp species, total molluscs, and pooled mollusc species. Variables that met the assumptions were examined by paired Student's $t$-tests (2-tailed). Non-parametric Wilcoxon sign rank tests were used for the remaining variables. The sequential Bonferroni correction was used to reduce multiple comparison testing error (Holm 1979). Rank-abundance plots were constructed as a representation of community diversity. All statistical analyses were performed using SAS Version 8.0 (SAS Institute 1999).

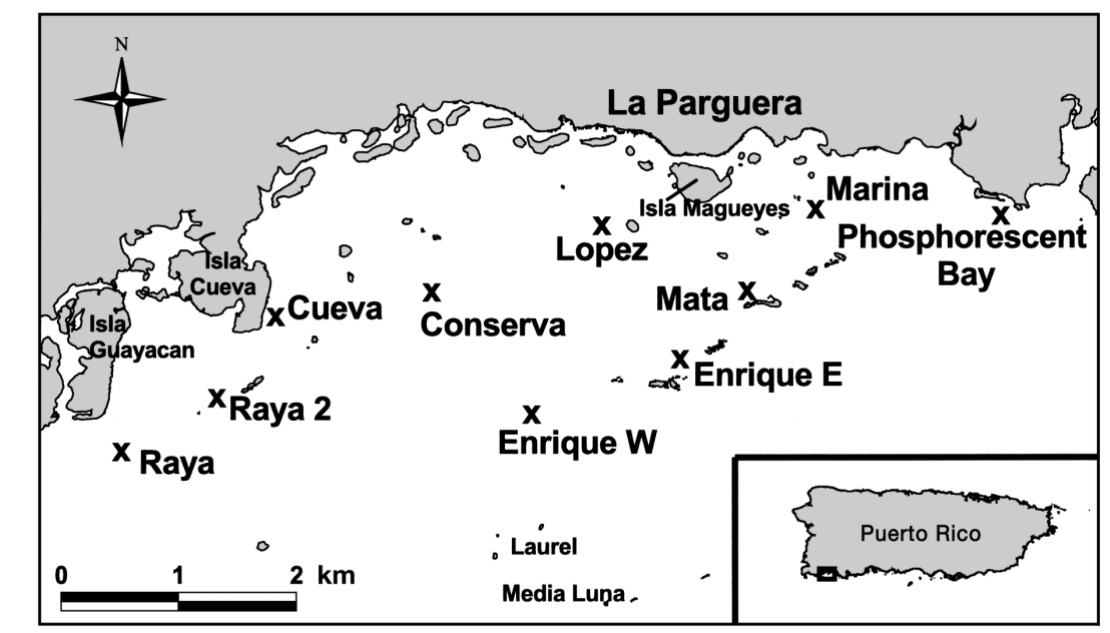

Fig. 1. Map of the shoreline and associated reefs near La Parguera, Puerto Rico. $\mathbf{x}$ : location of each study site 
Table 1. Summary of total macrofauna and decapods (no. $\mathrm{m}^{-2} \pm \mathrm{SE}$ ) and total species collected from within each seagrass-bed (Thalassia testudinum) zone $(\mathrm{n}=10)$

\begin{tabular}{|c|c|c|c|c|c|c|}
\hline Taxonomic group & No. of individuals & $\%$ of total & Scar & Edge & $5 \mathrm{~m}$ & $10 \mathrm{~m}$ \\
\hline Total macrofauna & & & $67.7(18.3)$ & $200.0(41.1)$ & $203.2(43.5)$ & $283.2(23.8)$ \\
\hline Total no. of species & & & $1.6(0.3)$ & $5.0(0.7)$ & $5.2(0.7)$ & $6.2(0.5)$ \\
\hline Total shrimp & 559 & 100 & $23.5(4.5)$ & $89.6(21.2)$ & $78.0(14.7)$ & $105.5(20.0)$ \\
\hline Thor manningi & 137 & 24.5 & $1.6(1.6)$ & $25.0(6.5)$ & $15.5(5.1)$ & $29.3(10.1)$ \\
\hline \multicolumn{7}{|l|}{ Hippolyte zostericola/ } \\
\hline pleuracanthus a & 128 & 22.9 & $1.6(1.1)$ & $21.3(10.5)$ & $17.1(6.0)$ & $28.3(21.9)$ \\
\hline Alpheus normanni & 109 & 19.5 & $8.0(3.0)$ & $12.3(5.4)$ & $19.7(4.1)$ & $18.1(7.0)$ \\
\hline Periclimenes americanus & 75 & 13.4 & $4.3(2.1)$ & $12.3(5.2)$ & $9.1(2.6)$ & $14.4(6.3)$ \\
\hline Latreutes fucorum & 71 & 12.7 & $1.1(0.7)$ & $14.4(4.6)$ & $13.9(4.3)$ & $8.5(4.2)$ \\
\hline Trachypenaeus sp. ${ }^{\mathrm{b}}$ & 14 & 2.5 & $4.3(3.2)$ & $1.1(0.7)$ & $1.1(0.7)$ & $1.1(1.1)$ \\
\hline Processa bermudensis ${ }^{\mathrm{b}}$ & 12 & 2.1 & $1.6(1.1)$ & $1.1(1.1)$ & $0(0)$ & $3.7(1.4)$ \\
\hline Leander tenuicornis ${ }^{\mathrm{b}}$ & 6 & 1.1 & $0(0)$ & $1.6(0.8)$ & $0(0)$ & $1.8(0.9)$ \\
\hline Latreutes parvulus ${ }^{\mathrm{b}}$ & 2 & 0.4 & $0(0)$ & $0.5(0.5)$ & $0.5(0.5)$ & $0(0)$ \\
\hline Tozeuma carolinense ${ }^{\mathrm{b}}$ & 2 & 0.4 & $0.5(0.5)$ & $0(0)$ & $0(0)$ & $0.5(0.5)$ \\
\hline Sicyonia laevigata ${ }^{\mathrm{b}}$ & 1 & 0.2 & $0(0)$ & $0(0)$ & $0.5(0.5)$ & $0(0)$ \\
\hline $\begin{array}{l}\text { Farfantepenaeus } \\
\text { duorarum }^{\text {b }}\end{array}$ & 1 & 0.2 & $0(0)$ & $0(0)$ & $0.5(0.5)$ & $0(0)$ \\
\hline Metapenaeopsis goodei ${ }^{\mathrm{b}}$ & 1 & 0.2 & $0.5(0.5)$ & $0(0)$ & $0(0)$ & $0(0)$ \\
\hline Pooled shrimp & 39 & 7.0 & $6.9(3.0)$ & $4.3(1.7)$ & $2.7(1.2)$ & $6.9(1.1)$ \\
\hline Total crabs & 369 & 100 & $29.9(10.8)$ & $39.5(10.6)$ & $44.3(7.6)$ & $83.2(13.7)$ \\
\hline Brachyura & 251 & 68.0 & $22.9(7.3)$ & $31.0(9.1)$ & $31.5(5.1)$ & $48.5(7.2)$ \\
\hline Anomura & 118 & $32.0(4.1)$ & $7.0(9.3)$ & $8.5(14.2)$ & $12.8(14.9)$ & 34.7 \\
\hline
\end{tabular}

\section{RESULTS}

Total fauna

Propeller scars had fewer animals than the surrounding seagrass (Tables $1 \& 2$ ). In addition, the edge and $5 \mathrm{~m}$ zones contained fewer total animals than the $10 \mathrm{~m}$ zone (Table 2). Scars also had fewer species than the other zones (Tables $1 \& 2$ ).

\section{Decapods}

Fourteen shrimp species (Decapoda) were collected (Table 1); 5 species accounted for $92.2 \%$ of the total number of shrimp (Table 1). The total number of shrimp per $\mathrm{m}^{2}$ was lower in scars when compared to the edge, $5 \mathrm{~m}$, and $10 \mathrm{~m}$ zones (Tables 1 \& 2). No other zone comparisons were different (Table 2). Shrimp species densities were generally lower in the scars than in the other zones (Table 2). There were no significant differences in Periclimenes americanus densities among any of the zones (Table 2). Shrimp assemblages in scars differed from the adjacent seagrass (Fig. 2, Table 2). Thor manningi and Hippolyte zostericola/pleuracanthus, dominant seagrass occupants, were not as proportionally abundant in the scars as in the seagrass. Alpheus nor- manni and Trachypenaeus sp. represented the highest proportion of shrimp in scars. Rank abundance plots indicated low evenness across all zones, although scars were more even than seagrass (Fig. 2).

Brachyurans were the dominant crab group, comprising $68.0 \%$ of the total crabs collected (Table 1). Brachyuran densities were significantly lower in the scar and $5 \mathrm{~m}$ zones than in the $10 \mathrm{~m}$ zone (Table 2). Anomuran densities exhibited no significant differences across zones (Table 2). There were significantly lower numbers of total crabs in the scar, edge, and $5 \mathrm{~m}$ zones than in the $10 \mathrm{~m}$ zone (Table 2).

\section{Molluscs}

Four species accounted for $60.7 \%$ of the total molluscs (Table 3). Total mollusc density was significantly lower in scars versus all other zones, and densities in the edge and $5 \mathrm{~m}$ zones were significantly lower than the $10 \mathrm{~m}$ zone (Table 4). There were no significant differences among zones for Cerithium eberneum (Table 4). No Cerithiopsis greeni were collected from scars (Table 3). Modulus modulus, the third most abundant mollusc, had significantly lower densities in scars than in the $10 \mathrm{~m}$ zone (Tables 3 \& 4). Tricolia bella densities were significantly lower in the scar versus all 
Table 2. $\mathrm{p}$-values resulting from paired, 2-tailed $t$-tests comparing differences in mean total macrofauna (no. $\mathrm{m}^{-2}$ ), mean total species $\left(0.25 \mathrm{~m}^{-2}\right)$, and mean no. of decapods $\mathrm{m}^{-2}$ between pairs of seagrass-bed zones. * significant at the per-contrast error rate $(\alpha=0.05) ;{ }^{* *}$ significant after correcting for multiple comparisons

\begin{tabular}{|c|c|c|c|c|c|c|}
\hline Taxonomic group & Scar vs edge & Scar vs $5 \mathrm{~m}$ & Scar vs $10 \mathrm{~m}$ & Edge vs $5 \mathrm{~m}$ & Edge vs $10 \mathrm{~m}$ & $5 \mathrm{vs} 10 \mathrm{~m}$ \\
\hline Total macrofauna & $<0.0001^{* *}$ & $<0.0001^{* *}$ & $<0.0001^{* *}$ & 0.965 & $0.002^{* *}$ & $0.004^{* *}$ \\
\hline Total no. of species & $0.0004^{* *}$ & $0.0001^{* *}$ & $<0.0001^{* *}$ & 0.602 & 0.135 & 0.203 \\
\hline Total shrimp & $0.006^{* *}$ & $0.002^{* *}$ & $0.002^{* *}$ & 0.506 & 0.236 & 0.126 \\
\hline Thor manningi & $0.001^{* *}$ & $0.027^{*}$ & $<0.0001^{* *}$ & 0.104 & 0.850 & 0.141 \\
\hline $\begin{array}{l}\text { Hippolyte zostericola/ } \\
\text { pleuracanthus }^{\mathrm{a}}\end{array}$ & $0.006^{* *}$ & $0.008^{* *}$ & $0.0004^{* *}$ & 0.616 & 0.197 & 0.154 \\
\hline Alpheus normanni & 0.564 & $0.023^{*}$ & 0.252 & 0.238 & 0.066 & 0.824 \\
\hline Periclimenes americanus & 0.173 & 0.151 & 0.116 & 0.901 & 0.616 & 0.454 \\
\hline Latreutes fucorum & $0.029^{*}$ & $0.013^{*}$ & 0.075 & 0.746 & 0.570 & 0.431 \\
\hline Pooled shrimp ${ }^{b}$ & 0.213 & 0.122 & 0.399 & 0.434 & $0.030^{*}$ & $0.005^{* *}$ \\
\hline Total crabs & 0.457 & 0.261 & $0.020^{*}$ & 0.711 & $0.031^{*}$ & $0.003^{* *}$ \\
\hline Brachyura & 0.505 & 0.359 & $0.041^{*}$ & 0.952 & 0.092 & $0.023^{*}$ \\
\hline Anomura & 0.364 & 0.489 & 0.074 & 0.971 & 0.148 & 0.074 \\
\hline
\end{tabular}
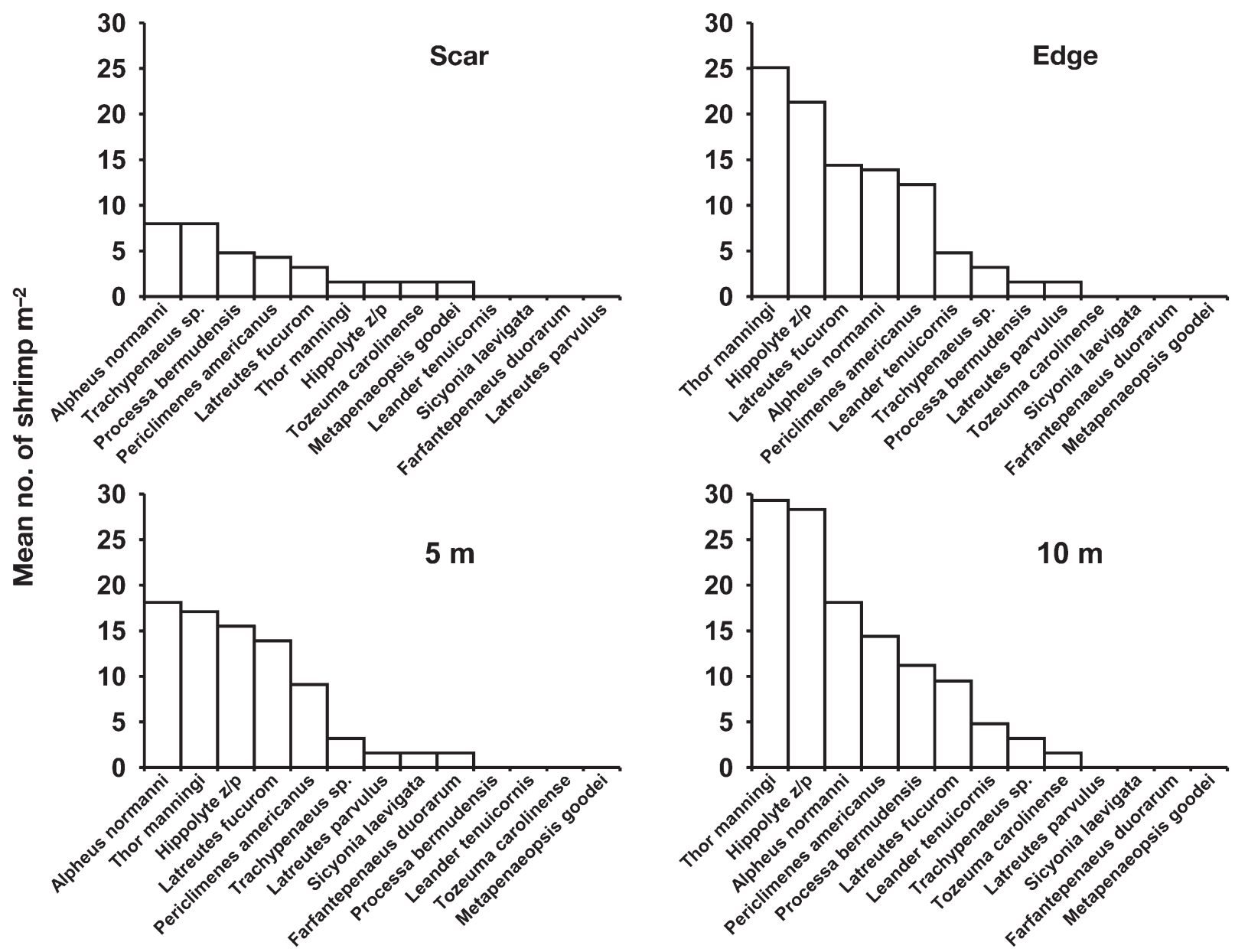

Fig. 2. Shrimp rank abundance plots for all seagrass-bed zones. Absence of bars indicates no individuals were collected. Hippolyte $\mathrm{z} / \mathrm{p}=$ Hippolyte zostericola/pleuracanthus 
Table 3. Summary of molluscs (no. $\mathrm{m}^{-2} \pm \mathrm{SE}$ ) collected from within each seagrass-bed (Thalassia testudinum) zone $(\mathrm{n}=10)$

\begin{tabular}{|c|c|c|c|c|c|c|}
\hline Mollusc taxon & No. of individuals & $\%$ of total & Scar & Edge & $5 \mathrm{~m}$ & $10 \mathrm{~m}$ \\
\hline Total molluscs & 460 & 100 & $11.2(4.1)$ & $67.7(30.2)$ & $76.8(34.5)$ & $89.6(20.6)$ \\
\hline Cerithium eberneum & 147 & 32.0 & $4.8(3.2)$ & $22.9(16.1)$ & $24.1(14.2)$ & $26.6(13.5)$ \\
\hline Cerithiopsis greeni & 48 & 10.4 & $0(0)$ & $7.5(2.3)$ & $11.7(9.5)$ & $6.4(2.5)$ \\
\hline Modulus modulus & 44 & 9.6 & $1.1(0.7)$ & $5.3(2.5)$ & $6.4(3.5)$ & $10.7(3.0)$ \\
\hline Tricolia bella & 40 & 8.7 & $0.5(0.5)$ & $4.8(1.5)$ & $8.5(4.6)$ & $7.5(2.3)$ \\
\hline Tegula fasciata ${ }^{a}$ & 27 & 5.9 & $0(0)$ & $1.6(0.8)$ & $3.7(2.5)$ & $9.1(4.4)$ \\
\hline Acmaea sp. ${ }^{\mathrm{a}}$ & 22 & 4.8 & $0(0)$ & $3.7(1.8)$ & $4.3(1.3)$ & $4.8(2.2)$ \\
\hline Anachis pulchella ${ }^{\mathrm{a}}$ & 19 & 4.1 & $0(0)$ & $3.7(2.8)$ & $1.6(0.8)$ & $4.3(1.7)$ \\
\hline Nassarius albus ${ }^{\mathrm{a}}$ & 17 & 3.7 & $2.1(1.4)$ & $4.8(3.4)$ & $1.6(1.6)$ & $2.7(1.8)$ \\
\hline Turbo castanea ${ }^{\mathrm{a}}$ & 16 & 3.5 & $0(0)$ & $3.2(2.1)$ & $5.3(3.4)$ & $1.1(0.7)$ \\
\hline Ischnochiton $\mathrm{sp}^{\mathrm{a}}$ & 14 & 3.0 & $1.1(0.7)$ & $0.5(0.5)$ & $4.7(2.1)$ & $0.6(0.6)$ \\
\hline Smaragdia viridis ${ }^{\mathrm{a}}$ & 14 & 3.0 & $0(0)$ & $3.2(2.7)$ & $3.6(2.5)$ & $1.2(0.8)$ \\
\hline Arene tricarinata $^{a}$ & 10 & 2.2 & $0(0)$ & $1.1(0.7)$ & $0(0)$ & $4.3(2.5)$ \\
\hline Bulla striata ${ }^{a}$ & 7 & 1.5 & $0(0)$ & $0.5(0.5)$ & $0(0)$ & $3.2(3.2)$ \\
\hline Acanthochitona pygmaea & 6 & 1.3 & $0(0)$ & $0(0)$ & $0.5(0.5)$ & $2.7(1.6)$ \\
\hline Crepidula convexa ${ }^{\mathrm{a}}$ & 5 & 1.1 & $0(0)$ & $0.5(0.5)$ & $0.5(0.5)$ & $1.6(1.1)$ \\
\hline Crassinella guadalupensis & 4 & 0.9 & $0(0)$ & $1.1(1.1)$ & $0.5(0.5)$ & $0.5(0.5)$ \\
\hline Diodora sp. ${ }^{\mathrm{a}}$ & 2 & 0.4 & $0(0)$ & $1.1(0.7)$ & $0(0)$ & $0(0)$ \\
\hline Cerithium litteratum $^{\mathrm{a}}$ & 2 & 0.4 & $0(0)$ & $0(0)$ & $0(0)$ & $1.1(0.7)$ \\
\hline Columbella mercatoria ${ }^{a}$ & 2 & 0.4 & $0(0)$ & $0.5(0.5)$ & $0.5(0.5)$ & $0(0)$ \\
\hline Engoniophos unicinctus ${ }^{\mathrm{a}}$ & 2 & 0.4 & $1.1(1.1)$ & $0(0)$ & $0(0)$ & $0(0)$ \\
\hline Olivella floralia ${ }^{\mathrm{a}}$ & 2 & 0.4 & $0(0)$ & $1.1(1.1)$ & $0(0)$ & $0(0)$ \\
\hline Fissurella sp. $^{\mathrm{a}}$ & 1 & .2 & $0(0)$ & $0(0)$ & $0.5(0.5)$ & $0(0)$ \\
\hline Brachiodontus exustus $^{\mathrm{a}}$ & 1 & 0.2 & $0(0)$ & $0.5(0.5)$ & $0(0)$ & $0(0)$ \\
\hline Antillophos sp. ${ }^{\mathrm{a}}$ & 1 & 0.2 & $0(0)$ & $0(0)$ & $0(0)$ & $0.5(0.5)$ \\
\hline Arene sp. ${ }^{\mathrm{a}}$ & 1 & 0.2 & $0(0)$ & $0(0)$ & $0(0)$ & $0.5(0.5)$ \\
\hline Astraea phoebia $^{\mathrm{a}}$ & 1 & 0.2 & $0(0)$ & $0(0)$ & $0.5(0.5)$ & $0(0)$ \\
\hline Conus jaspidus ${ }^{\mathrm{a}}$ & 1 & 0.2 & $0(0)$ & $0.5(0.5)$ & $0(0)$ & $0(0)$ \\
\hline Cerithiopsis emersoni $^{\text {a }}$ & 1 & 0.2 & $0(0)$ & $0.5(0.5)$ & $0(0)$ & $0(0)$ \\
\hline Leucozonia sp. $^{\text {a }}$ & 1 & 0.2 & $0.5(0.5)$ & $0(0)$ & $0(0)$ & $0(0)$ \\
\hline Fam. Columbellidae ${ }^{a}$ & 1 & 0.2 & $0(0)$ & $0(0)$ & $0(0)$ & $0.5(0.5)$ \\
\hline Fam. Turridae $\mathrm{a}^{\mathrm{a}}$ & 1 & 0.2 & $0(0)$ & $0(0)$ & $0(0)$ & $0.5(0.5)$ \\
\hline Pooled molluscs & 181 & 39.3 & $4.8(1.9)$ & $27.2(10.7)$ & $26.1(5.9)$ & $38.4(6.6)$ \\
\hline \multicolumn{7}{|l|}{ a Pooled molluscs } \\
\hline
\end{tabular}

other zones (Table 4). Scar densities of pooled molluscs were significantly lower than those in the other zones, and densities in the $5 \mathrm{~m}$ zone were significantly lower than those in the $10 \mathrm{~m}$ zone (Tables $3 \& 4$ ).

\section{Fish}

Two fish species accounted for $76.9 \%$ of the total and dominated all zones (Table 5). For total number of fish, only the comparison of the edge and $10 \mathrm{~m}$ zones was significantly different (Table 6). Neither of the 2 most abundant fish species exhibited differences across the zones.

\section{DISCUSSION}

The abundance and composition of seagrass fauna observed in this study are similar to those reported from other studies in Puerto Rico (Martin \& Cooper 1981, Bauer 1985a,b, Eckrich \& Holmquist 2000) and the Caribbean (Heck 1977). In addition, the Puerto
Rican fauna can be compared with that of temperate Thalassia testudinum meadows in Florida. Examining the 10 most common decapod species in Puerto Rico (Bauer 1985a,b, Eckrich \& Holmquist 2000, Uhrin 2001), Florida Bay (Holmquist et al. 1989), the Indian River (Gore et al. 1981), Tampa Bay (Lewis 1984, Fonseca et al. 1996), and Apalachee Bay (Hooks et al. 1976, Lewis \& Stoner 1983), one can see a general decline in similarity of species complement as latitude increases. If the presence of congenerics is considered, these systems become more similar.

Natural bare substrates contain fewer total macrofauna and fewer species than adjacent seagrass (O'Gower \& Wacasey 1967, Stoner 1980, Orth et al. 1984) as did the bare sand trenches created by propeller scarring studied here. These differences were also evident when comparing macrofaunal groups. For example, the shrimp sampled in this study exhibited significantly reduced abundances in propeller scars. Seagrass offers refuge from predators, and experiments have shown that some shrimp species are less vulnerable to predation in vegetated versus bare 
Table 4. $\mathrm{p}$-values resulting from paired, 2-tailed $t$-tests comparing differences in mean no. of molluscs $\mathrm{m}^{-2}$ between pairs of seagrass-bed zones. ${ }^{*}$ significant at the per-contrast error rate $(\alpha=0.05){ }_{i}{ }^{* *}$ significant after correcting for multiple comparisons; $\left({ }^{* *}\right)$ denotes significance although a $t$-test was not possible

\begin{tabular}{|c|c|c|c|c|c|c|}
\hline Mollusc taxon & Scar vs edge & Scar vs $5 \mathrm{~m}$ & Scar vs $10 \mathrm{~m}$ & Edge vs $5 \mathrm{~m}$ & Edge vs $10 \mathrm{~m}$ & 5 vs $10 \mathrm{~m}$ \\
\hline Total molluscs & $0.0002^{* *}$ & $0.0009^{* *}$ & $0.0002^{* *}$ & 0.691 & $0.014^{* *}$ & $0.020^{* *}$ \\
\hline Cerithium eberneum & 0.109 & 0.197 & $0.031^{*}$ & 0.866 & 0.360 & 0.132 \\
\hline Cerithiopsis greeni & $\left({ }^{* *}\right)$ & $\left({ }^{* *}\right)$ & $\left({ }^{* *}\right)$ & 0.169 & 0.280 & 0.408 \\
\hline Modulus modulus & 0.094 & 0.295 & $0.002^{* *}$ & 0.586 & 0.094 & 0.057 \\
\hline Tricolia bella & $0.006^{* *}$ & $0.016^{*}$ & $0.003^{* *}$ & 0.857 & 0.558 & 0.663 \\
\hline Pooled molluscs ${ }^{\mathrm{a}}$ & $0.0008^{* *}$ & $0.001^{* *}$ & $0.0009^{* *}$ & 0.409 & 0.078 & $0.034^{*}$ \\
\hline
\end{tabular}

Table 5. Summary of fish (no. $\mathrm{m}^{-2} \pm \mathrm{SE}$ ) collected from within each seagrass-bed (Thalassia testudinum) zone $(\mathrm{n}=10)$

\begin{tabular}{|c|c|c|c|c|c|c|}
\hline Fish taxon & No. of individuals & $\%$ of total & Scar & Edge & $5 \mathrm{~m}$ & $10 \mathrm{~m}$ \\
\hline Total fish & 26 & 100 & $3.2(1.4)$ & $2.6(2.1)$ & $3.2(1.4)$ & $5.3(2.7)$ \\
\hline Bathygobius curacao & 14 & 53.8 & $1.1(0.7)$ & $2.1(2.1)$ & $1.1(1.1)$ & $3.7(2.7)$ \\
\hline Malacotenus macropus & 6 & 23.1 & $0.5(0.5)$ & $0.5(0.5)$ & $1.6(1.1)$ & $0.5(0.5)$ \\
\hline Gobionellus saepepallans & 2 & 7.7 & $1.1(1.1)$ & $0(0)$ & $0(0)$ & $0(0)$ \\
\hline Fam Gobiidae $^{\mathrm{a}}$ & 1 & 3.9 & $0.5(0.5)$ & $0(0)$ & $0(0)$ & $0(0)$ \\
\hline Coryphopterus sp. ${ }^{\mathrm{a}}$ & 1 & 3.9 & $0(0)$ & $0(0)$ & $0(0)$ & $0.5(0.5)$ \\
\hline Bryx dunckeri ${ }^{\mathrm{a}}$ & 1 & 3.9 & $0(0)$ & $0(0)$ & $0(0)$ & $0.5(0.5)$ \\
\hline Sparisoma sp. ${ }^{\mathrm{a}}$ & 1 & 3.9 & $0(0)$ & $0(0)$ & $0.5(0.5)$ & $0(0)$ \\
\hline Pooled fish & 6 & 23.1 & $1.6(1.1)$ & $0(0)$ & $0.5(0.5)$ & $1.1(0.7)$ \\
\hline
\end{tabular}

Table 6. p-values resulting from paired, 2-tailed $t$-tests comparing differences in mean no. of fish $\mathrm{m}^{-2}$ between pairs of seagrassbed (Thalassia testudinum) zones. ${ }^{*}$ significant at the per-contrast error rate $(\alpha=0.05) ;\left({ }^{* *}\right)$ denotes significance although a $t$-test was not possible

\begin{tabular}{|lcccccc|}
\hline Fish taxon & Scar vs edge & Scar vs 5 m & Scar vs 10 m & Edge vs 5 m & Edge vs 10 m & 5 vs $10 \mathrm{~m}$ \\
\hline Total fish & 0.722 & 1.000 & 0.434 & 0.777 & $0.037^{*}$ & 0.541 \\
Malacotenus macropus & 1.000 & 0.500 & 1.000 & 0.750 & 1.000 & 0.750 \\
Bathygobius curacao & 1.000 & 1.000 & 0.500 & 1.000 & 0.500 & 0.500 \\
Pooled fish & $\left({ }^{* *}\right)$ & 0.675 & 0.139 & $\left({ }^{* *}\right)$ & & \\
a Pooled fish as in Table 5 & & & & & \\
\hline
\end{tabular}

substrates (Coen et al. 1981, Heck \& Thoman 1981). Other species, such as caridean shrimp, are known to select vegetation over bare substrates (Ewald 1969, Barry 1974, Coen et al. 1981). Considering that scarring removes habitat (and shelter), shrimp probably emigrated to seagrass surrounding the scars or failed to immigrate into scar areas.

Scarring was found to modify species dominance for certain numerically abundant shrimp taxa. For example, species known to utilize the blades of seagrasses, such as Thor manningi and Hippolyte zostericola/ pleuracanthus, dominated seagrass edge and interior zones but showed significantly decreased abundances in scars as might be expected. In comparison, Alpheus normanni and Trachypenaeus sp., often associated with bare sand patches (Holmquist 1992), were the most abundant shrimp in scars.
The sampled molluscs are epifaunal on seagrass blades and the associated sediment. In conjunction with the direct loss of seagrass habitat, the churning action of the propeller may displace or redistribute these organisms, and habitat selection probably plays a role as well. For example, Lovegrove (1997) found decreased abundances of taxa with restricted motility (copepods and hermit crabs) in scarred versus reference beds. We suspect the same is true for molluscs in our study.

For more mobile organisms, scars may not present a significant boundary to movement. Highly mobile species may be less sensitive to boundaries and patch configuration (Wiens et al. 1985, Kotliar \& Wiens 1990, Wiens 1992), which appears to be the case for some seagrass fauna (Holmquist 1998). Bell et al. (2002) observed pinfish utilizing propeller scars in seagrass beds as corridors. The fish in our study may not have 
responded to the patch scale $(0.3$ to $0.8 \mathrm{~m}$ wide trenches) produced by propeller scars.

Crabs and molluscs exhibited a negative edge effect with significantly decreased abundances of these taxa up to a distance of $5 \mathrm{~m}$ from scars. Changes in predation rates at scar edges may play a part in structuring the distribution of crabs and molluscs in scarred areas. Peterson et al. (2001) found significantly shorter survival times for tethered crustaceans in Thalassia testudinum edge habitat $(<2 \mathrm{~m}$ from unvegetated substrate) versus the interior ( $>5 \mathrm{~m}$ from the edge) of the bed. Larger fish, such as snapper and grunts, were observed in scars, especially scars with exposed rhizomes at the margins (A. Uhrin pers. obs.). Perhaps these larger predators, known to consume crustaceans and molluscs (J. Holmquist pers. obs., Bölke \& Chaplin 1968), utilize scars as alleys, with quick forays into the fringing seagrass to feed (e.g. Bell et al. 2002). This behavior has also been observed in salt marsh predators that use unvegetated channels in the marsh as alleyways (Peterson \& Turner 1994, Kneib 2000). Examination of the responses of less vagile organisms to natural seagrass bed edges is limited and yields mixed results. Bologna \& Heck (1999) found higher densities of scallops in natural seagrass bed edges (within $1 \mathrm{~m}$ of the sand-grass interface) versus the bed interior (10 $\mathrm{m}$ from the interface) from T. testudinum beds in the northeast Gulf of Mexico, even though higher scallop predation rates were observed in the edges. The authors suggested that scallops trade off higher predation rates for the significantly higher growth rates obtained at seagrass edges (Bologna \& Heck 1999). Bell et al. (2001) reported significantly reduced densities of the infaunal polychaete, Kingbergonuphis simoni, at T. testudinum edges ( $1 \mathrm{~m}$ from the sand-grass interface) compared to densities $9 \mathrm{~m}$ from the interface in Tampa Bay, Florida. In contrast with our study, Bologna \& Heck (2002) found that pagurid crabs exhibited no significant density differences between natural seagrass bed edges and interiors.

The creation of edge habitat via scarring was not reflected by changes in shrimp abundance within seagrass surrounding scars. The intact seagrass surrounding the scars provides a deep pool of immigrants. For example, caridean shrimp have been shown to be highly mobile (Howard 1985, Stoner \& Lewis 1985, Sogard 1989) and it is possible that shrimp congregate in the seagrass surrounding scars when exposed to bare substrate (active refuge seeking; Sogard 1989, Bell et al. 2002). Our findings are similar to results from natural seagrass edges. Bologna \& Heck (2002) found no difference in caridean shrimp densities between edge (within $1 \mathrm{~m}$ of the sand-grass interface) and interior (10 $\mathrm{m}$ from the interface) portions of a Thalassia testudinum bed in the northeast Gulf of Mexico. Interestingly, Eggleston et al. (1998, 1999) found that for isolated seagrass patches within a sand matrix, grass shrimp Palaemonetes spp. densities increased with decreasing sizes of seagrass patches, indicating that these species were responding positively to edges. Shrimp in unvegetated areas would tend to seek protection in the nearest available habitat ('nearest refuge' hypothesis; Virnstein \& Curran 1986); in this case, isolated seagrass patches. In contrast, the propeller scars in our study represent only a small area of unsuitable habitat surrounded by intact seagrass. The 'nearest refuge' hypothesis is unlikely to produce a positive edge effect near propeller scars.

The results of our study are directly applicable to the assessment of seagrass community injuries. Our results show that ecological changes resulting from propeller scarring are not limited to the footprint of the scar, but can extend some distance away from the scar depending upon the faunal taxa under consideration. Some apparent effects were seen $5 \mathrm{~m}$ from scars. In seagrass beds with extensive scarring, there is the potential for sensitive taxa to disappear because significant amounts of the bed would be within this 'edge' habitat. When considering an injured bed for restoration, the distributions of fauna in comparable, undisturbed areas should first be established in order to determine which species have been impacted negatively and to what extent. As restoration proceeds, the distributions of impacted fauna can be monitored for recovery.

This study addressed issues pertaining to single scar disturbances. In contrast, when areas become riddled with scars, there is proportionally less seagrass coverage and biomass, and more edge habitat. Bed edges erode, leading to increased sediment suspension, and current flow may be altered (Walker et al. 1989, Fonseca 1996). Given that current patterns and velocities have the potential to shape seagrass beds (Fonseca et al. 1983), continual scarring may further degrade and restructure beds, leading to fragmentation of once continuous meadows (see Walker et al. 1989). Will the faunal effects observed in our study scale-up linearly, exponentially, or not at all? Initial work by Bell et al. (2002) at larger spatial scales suggests that the answers may be complex.

Acknowledgements. We would like to thank E. Weil, E. Williams, L. Williams, and P. Yoshioka for critiquing the manuscript. We benefited from discussions with A. BowdenKerby, D. Colby, C. Eckrich, M. Fonseca, K. Hammerstrom, R. Macchiavelli, M. Nemeth, A. Ortíz, B. Roque, H. Ruíz, J. Schmidt-Gengenbach, B. Shank, M. Sharer, and S. Slade. We would also like to thank 3 anonymous reviewers for their careful review and suggestions. This work was supported by funding from the PADI Foundation (to A.V.U.) and US Army Research Office Grant DAAH 04-95-10308 (to J.G.H.). 


\section{LITERATURE CITED}

Barberá-Cebrián C, Sánchez-Jerez P, Ramos-Esplá AA (2002) Fragmented seagrass habitats on the Mediterranean coast, and distribution and abundance of mysid assemblages. Mar Biol 141:405-413

Barry CA (1974) Role of form vision in habitat selection of the grass shrimp Hippolyte californiensis. Mar Biol 26: 261-270

Bauer RT (1985a) Diel and seasonal variation in species composition and abundance of Caridean shrimps (Crustacea, Decapoda) from seagrass meadows on the north coast of Puerto Rico. Bull Mar Sci 36:150-162

Bauer RT (1985b) Penaeoid shrimp fauna from tropical seagrass meadows: species composition, diurnal, and seasonal variation in abundance. Proc Biol Soc Wash 98:177-190

Bell SS, Brooks RA, Robbins BD, Fonseca MS, Hall MO (2001) Faunal response to fragmentation in seagrass habitats: implications for seagrass conservation. Biol Conserv 100: 115-123

Bell SS, Hall MO, Soffian S, Madley K (2002) Assessing the impact of boat propeller scars on fish and shrimp utilization of seagrass beds. Ecol Appl 12:206-217

Bender DJ, Contresas TA, Fahrig L (1998) Habitat loss and population decline: a meta-analysis of the patch-size effect. Ecology 79:517-532

Bölke JE, Chaplin CCG (1968) Fishes of the Bahamas and adjacent tropical waters. Livingston Publishing Company, Wynnewood, PA

Bologna PAX, Heck KL Jr (1999) Differential predation and growth rates of bay scallops within a seagrass habitat. J Exp Mar Biol Ecol 239:299-314

Bologna PAX, Heck KL Jr (2002) Impact of habitat edges on density and secondary production of seagrass-associated fauna. Estuaries 25:1033-1044

Burdick DM, Short FT (1999) The effects of boat docks on eelgrass beds in coastal waters of Massachusetts. Environ Manage 23:231-240

Coen LD, Heck KL Jr, Abele LG (1981) Experiments on competition and predation among shrimps of seagrass meadows. Ecology 62:1484-1493

Creed JC, Amado Filho GM (1999) Disturbance and recovery of the macroflora of a seagrass (Halodule wrightii Ascherson) meadow in the Abrolhos Marine National Park, Brazil: an experimental evaluation of anchor damage. J Exp Mar Biol Ecol 235:285-306

Dawes CJ, Andorfer J, Rose C, Uranowski C, Ehringer N (1997) Regrowth of the seagrass Thalassia testudinum into propeller scars. Aquat Bot 59:139-155

Doak DF, Marino PC, Kareiva PM (1992) Spatial scale mediates the influence of habitat fragmentation on dispersal success: implications for conservation. Theor Popul Biol 41:315-336

Durako MJ, Hall MO, Sargent F, Peck S (1992) Propeller scars in seagrass beds: an assessment and experimental study of recolonization in Weedon Island State Preserve, Florida. In: Webb FJ Jr (ed) Proc 19th Annu Conf Wetlands Restoration and Creation. Hillsborough Community College, Plant City, FL, p 42-53

Eckrich CE, Holmquist JG (2000) Trampling in a seagrass assemblage: direct effects, response of associated fauna, and the role of substrate characteristics. Mar Ecol Prog Ser 201:199-209

Eggleston DB, Etherington LL, Elis WE (1998) Organism response to habitat patchiness: species and habitatdependent recruitment of decapod crustaceans. J Exp Mar Biol Ecol 223:111-132
Eggleston DB, Elis WE, Etherington LL, Dahlgren CP, Posey MH (1999) Organism responses to habitat fragmentation and diversity: habitat colonization by estuarine macrofauna. J Exp Mar Biol Ecol 236:107-132

Eleuterius LN (1987) Seagrass ecology along the coasts of Alabama, Louisiana, and Mississippi. In: Durako MJ, Phillips RC, Lewis RR (eds) Proc Symp subtropical-tropical seagrasses of the southeastern United States. Florida Marine Research Institute Publication 42, St. Petersburg, FL, p 11-24

Ewald JJ (1969) Observations on the biology of Tozeuma carolinense from Florida with special reference to larval development. Bull Mar Sci 19:510-549

Fonseca MS (1994) A guide to transplanting seagrasses in the Gulf of Mexico. Sea Grant College Program TAMU-SG94-601. Texas A\&M University, College Station, Texas

Fonseca MS (1996) The role of seagrass in nearshore sedimentary processes: a review. In: Norstrom KF, Roman CJ (eds) Estuarine shores: evolution, environment, and human alteration. John Wiley \& Sons, New York, p 261-286

Fonseca MS, Fisher JS, Zieman JC, Thayer GW (1982) Influence of the seagrass, Zostera marina L., on current flow. Estuar Coast Shelf Sci 15:351-364

Fonseca MS, Zieman JC, Thayer GW, Fisher JS (1983) The role of current velocity in structuring eelgrass (Zostera marina L.) meadows. Estuar Coast Shelf Sci 17:367-380

Fonseca MS, Meyer DL, Hall MO (1996) Development of planted seagrass beds in Tampa Bay, Florida, USA. II. Faunal components. Mar Ecol Prog Ser 132:141-156

Forman RT (1995) Land mosaics: the ecology of landscapes and regions. Cambridge University Press, Cambridge

Frost MT, Rowden AA, Attrill MJ (1999) Effect of habitat fragmentation on the macroinvertebrate infaunal communities associated with the seagrass Zostera marina L. Aquat Conserv Mar Freshw Ecosyst 9:255-263

Gascon C, Williamson B, da Fonseca GAB (2000) Receding forest edges and vanishing reserves. Science 288:1356-1358

Gonzalez-Liboy J (1979) An examination of the present condition of seagrass meadows in La Parguera, Puerto Rico. Department of Natural Resources final report project no. F-4, San Juan, Puerto Rico

Gore RH, Gallaher EE, Scotto LE, Wilson KA (1981) Studies on decapod Crustacea from the Indian River region of Florida. XI. community composition, structure, biomass and species-areal relationships of seagrass and drift algae-associated macrocrustaceans. Estuar Coast Shelf Sci 12:485-508

Hastings K, Hesp P, Kendrick GA (1995) Seagrass loss associated with boat moorings at Rottnest Island, Western Australia. Ocean Coast Manage 26:225-246

Heck KL Jr (1977) Comparative species richness, composition, and abundance of invertebrates in Caribbean seagrass (Thalassia testudinum) meadows (Panamá). Mar Biol 41:335-348

Heck KL Jr, Thoman TA (1981) Experiments on predator-prey interactions in vegetated aquatic habitats. J Exp Mar Biol Ecol 53:125-134

Holm S (1979) A simple sequentially rejective multiple test procedure. Scand J Stat 6:65-70

Holmquist JG (1992) Disturbance, dispersal, and patch insularity in a marine benthic assemblage: influence of a mobile habitat on seagrasses and associated fauna. PhD thesis, Florida State University, Tallahassee, FL

Holmquist JG (1997) Disturbance and gap formation in a marine benthic mosaic: influence of shifting macroalgal patches on seagrass structure and indirect effects on mobile invertebrates. Mar Ecol Prog Ser 158:121-130 
Holmquist JG (1998) Permeability of patch boundaries to benthic invertebrates: influences of boundary contrast, light level, and faunal density and mobility. Oikos 81:558-566

Holmquist JG, Powell GVN, Sogard SM (1989) Decapod and stomatopod assemblages on a system of seagrass-covered mud banks in Florida Bay. Mar Biol 100:473-483

Hooks TA, Heck KL Jr, Livingston RJ (1976) An inshore marine invertebrate community: structure and habitat associations in the northeastern Gulf of Mexico. Bull Mar Sci 26:99-109

Howard RK (1985) Measurements of short-term turnover of epifauna within seagrass beds using an in situ staining method. Mar Ecol Prog Ser 22:163-168

Hurlbert SH (1984) Pseudoreplication and the design of ecological field experiments. Ecol Monogr 54:187-211

Kneib RT (2000) Salt marsh ecoscapes and production transfers by estuarine nekton in the southeastern United States. In: Weinstein MP, Kreeger DA (eds) Concepts and controversies in tidal marsh ecology. Kluwer Academic, London, p 267-291

Kotliar NB, Wiens JA (1990) Multiple scales of patchiness and patch structure: a hierarchical framework for the study of heterogeneity. Oikos 59:253-260

Lewis FG III (1984) Distribution of macrobenthic crustaceans associated with Thalassia, Halodule, and bare sand substrata. Mar Ecol Prog Ser 19:101-113

Lewis FG III, Stoner AW (1983) Distribution of macrofauna within seagrass beds: an explanation for patterns of abundance. Bull Mar Sci 33:296-304

Lovegrove S (1997) Assessment of the ecological effects of propeller damage from motor boats on a Thalassia testudinum (Banks ex Koenig) bed in Charlotte Harbor, Florida. MSc thesis, University of North Wales

Lovejoy TE, Bierregaard RO, Rylands AB, Malcolm JR and 7 others (1986) Edge and other effects of isolation on Amazon forest fragments. In: Soule ME (ed) Conservation biology: the science of scarcity and diversity. Sinauer Associates, Sunderland, MA, p 257-285

Majer JD, Delabie JHC, McKenzie NL (1997) Ant litter fauna of forest, forest edges and adjacent grasslands in the Atlantic rain forest region of Bahia, Brazil. Insect Soc 44: 255-266

Martin FD, Cooper M (1981) A comparison of fish faunas found in pure stands of two tropical Atlantic seagrasses, Thalassia testudinum and Syringodium filiforme. Northeast Gulf Sci 5:31-37

McNeill SE, Fairweather PG (1993) Single large or several small marine reserves? An experimental approach with seagrass fauna. J Biogeogr 20:429-440

O'Gower AK, Wacasey JW (1967) Animal communities associated with Thalassia, Diplanthera, and sand beds in Biscayne Bay I. Analysis of communities in relation to water movements. Bull Mar Sci 17:175-201

Orth RJ (1977) The importance of sediment stability in seagrass communities. In: Coull BC (ed) Ecology of marine benthos. University of South Carolina Press, Columbia, p 281-300

Orth RJ, Heck KL Jr, van Montfrans J (1984) Faunal communities in seagrass beds: a review of the influence of plant structure and prey characteristics on predator-prey relationships. Estuaries 7:339-350

Ozanne CMP, Hambler C, Foggo A, Speight MR (1997) The significance of edge effects in the management of forests for invertebrate biodiversity. In: Stork NE, Adis J, Didham

Editorial responsibility: Kenneth Heck (Contributing Editor), Dauphin Island, Alabama, USA
RK (eds) Canopy arthropods. Chapman and Hall, New York, p 534-550

Peterson GW, Turner RE (1994) The value of salt marsh edge vs interior as a habitat for fish and decapod crustaceans in a Louisiana tidal marsh. Estuaries 17:235-262

Peterson BJ, Thompson KR, Cowan JH Jr, Heck KL Jr (2001) Comparison of predation pressure in temperate and subtropical seagrass habitats based on chronographic tethering. Mar Ecol Prog Ser 224:77-85

Rozas LP, Minello TJ (1997) Estimating densities of small fishes and decapod crustaceans in shallow estuarine habitats: a review of sampling design with focus on gear selection. Estuaries 20:199-213

Sargent FJ, Leary TJ, Crewz DW, Kruer CR (1995) Scarring of Florida's seagrasses: assessment and management options. Florida Marine Research Institute Technical Report TR-1, Florida Marine Research Institute, St. Petersburg, FL

SAS Institute (1999) SAS Version 8.0. SAS Institute, Cary, NC

Saunders DA, Hobbs RJ, Margules CR (1991) Biological consequences of ecosystem fragmentation. Biol Conserv 5: 18-32

Sogard S (1989) Colonization of artificial seagrass by fishes and decapod crustaceans - importance of proximity to natural eelgrass. J Exp Mar Biol Ecol 133:15-37

Sogard SM, Powell GVN, Holmquist JG (1987) Epibenthic fish communities on Florida Bay banks: relations with physical parameters and seagrass cover. Mar Ecol Prog Ser 40:25-39

Stevens SM, Husband TP (1998) The influence of edge on small mammals: evidence from Brazilian Atlantic forest fragments. Biol Conserv 85:1-8

Stoner AW (1980) The role of seagrass biomass in the organization of benthic macrofaunal assemblages. Bull Mar Sci 30:537-551

Stoner AW, Lewis FG (1985) The influence of quantitative and qualitative aspects of habitat complexity in tropical seagrass meadows. J Exp Mar Biol Ecol 94:19-40

Strong AM, Bancroft GT (1994) Patterns of deforestation and fragmentation of mangrove and deciduous seasonal forests in the upper Florida Keys. Bull Mar Sci 54:795-804

Uhrin AV (2001) Propeller scarring in a seagrass assemblage: effects on seagrass, physical processes, and response of associated fauna. MSc thesis, University of Puerto Rico, Mayagüez

Virnstein RW, Curran MC (1986) Colonization of artificial seagrass versus time and distance from source. Mar Ecol Prog Ser 29:279-288

Walker DI, Lukatelich RJ, Bastyan G, McComb AJ (1989) Effect of boat moorings on seagrass beds near Perth, Western Australia. Aquat Bot 36:69-77

Wiens JA (1992) Ecological flows across landscape boundaries: a conceptual overview. In: Hansen AJ, diCastri F (eds) Landscape boundaries: consequences for biotic diversity and ecological flows. Springer-Verlag, New York, p 217-235

Wiens JA, Crawford CS, Gosz JR (1985) Boundary dynamics: a conceptual framework for studying landscape ecosystems. Oikos 45:421-427

Wilcox BA, Murphy DD (1985) Conservation strategy: the effects of fragmentation on extinction. Am Nat 125: 879-887

Zieman JC (1976) The ecological effects of physical damage from motor boats on turtle grass beds in southern Florida. Aquat Bot 2:127-139

Submitted: July 10, 2002; Accepted: November 14, 2002

Proofs received from author(s): March 4, 2003 